\title{
Integrated Water-Energy Policy for Sustainable Development
}

\author{
Daniel Sklarew \\ Associate Professor, dsklarew@gmu.edu \\ Jennifer Sklarew \\ Adjunct Professor, jsklarew@masonlive.gmu.edu \\ College of Science, George Mason University, Fairfax, Virginia, USA
}

Abstract

\begin{abstract}
$\mathrm{N}$ umerous studies indicate the close interdependence between the water and energy industries, given that energy production is usually characterized by high water consumption while increasing water availability requires significant energy costs. The integration of energy and water policies at the global and national levels is seen as a tool for achieving sustainable development goals. The paper analyzes the opportunities for countries to ensure equal access to clean water and electricity provided by such integration. The case studies of India, Ghana, and Morocco
\end{abstract}

\section{Keywords:}

electricity access; clean energy; water access; clean water; Sustainable Development Goals; Energy-Water Nexus; natural resource management; United Nations illustrate how to achieve success when applying the nexus approach to water and energy policies.

This study offers unique contributions by providing a pioneering analysis of the relationship between global goals for energy and water access and national governments' abilities to develop synergistic energy and water policies. The proposed approach to integrating energy and water use could be applied to the full range of sustainable development goals and will be crucial for the success of countries in their implementation.
Citation: Sklarew D., Sklarew J. (2018) Integrated WaterEnergy Policy for Sustainable Development. Foresight and STI Governance, vol. 12, no 4, pp. 10-19.

DOI: $10.17323 / 2500-2597.2018 .4 .10 .19$ 
$\mathrm{T}$ he 1992 Rio Declaration established a global consensus that "human beings are at the center of concerns for sustainable development." This agreement, in turn, catalyzed unprecedented international collaboration towards addressing current and future generations' needs and well-being [United Nations, 2015]. Our success hereafter depends upon implementing certain enabling conditions, such as eliminating chronic thirst and providing reliable, clean energy for everyone, everywhere. At the same time, negative externalities, such as harm to other life and climatic instability from our greenhouse gas (GHG) emissions, must be mitigated.

These ends are among the 17 Sustainable Development Goals (SDGs) that United Nations members and their partners in 2015 agreed to realize by 2030 [Sachs et al., 2018]:
1. No poverty
2. Zero hunger
3. Good health and well-being for people
4. Quality education
5. Gender equality
6. Clean water and sanitation
7. Affordable and clean energy
8. Decent work and economic growth
9. Industry, innovation, and infrastructure
10. Reduce inequality
11. Sustainable cities and communities
12. Responsible consumption and production
13. Climate action
14. Life below water
15. Life on land
16. Peace, justice, and strong institutions
17. Partnerships for achieving the above goals

How can these global goals for energy (SDG 7) and water (SDG 6) be achieved simultaneously and universally in the near future? Can we do so without irreparably impairing other ecosystem services (SDGs 13-15) upon which our life and collective prosperity depend?

Neither clean energy nor freshwater are in short supply on a global scale. Solar energy arriving to Earth's surface is some 7,500 times greater than our primary energy consumption of $450 \mathrm{EJ}$ per year [World Energy Council, 2013]. Meanwhile, Lake Baikal in Russia alone contains more than tenfold the freshwater that humanity consumes annually [ILEC, UNEP, 1993; Cosgrove, Rijsberman, 2000]. By around 2015, we withdrew about one eighth of all readily available freshwater resources [UN, 2018, SDG 6.4.2]. Thus, our generation's challenge hereafter for both clean energy and clean water is not one of global scarcity, but of global access.

The period of 2000-2015 was a prerequisite with respect to improving this access by 2030 . Over those fifteen years, humanity made remarkable strides towards global goals for universal access to clean energy and clean water.

Even as the global population grew by $38 \%$ from 2000 to 2015, the percentage of people with access to electric power increased by $10 \%$ to $87 \%$ [UN DESA, 2017; World Bank, 2018a]. At the same time, a steady $17 \%$ of total global energy consumption came from renewable sources - modern bioenergy, geothermal, hydropower, solar and wind, as well as traditional fuelwood and charcoal [World Bank, 2018a]. The net impact upon energy-related greenhouse gas (GHG) emissions was an increase of more than $40 \%$ over this period [IEA, 2018]. Thus, at the current development rate, we extrapolate that universal electricity access could be achieved before 2040. By contrast, clean energy for all, at least with respect to renewable energy without substantial GHG emissions, still appears generations away.

The World Health Organization/United Nations Children's Fund Joint Monitoring Program recognizes access to clean drinking water is expanding as well [WHO, UNICEF, 2017]. As with electricity, reliable on-site access to water grew by 10 percentage points, from $61 \%$ to $71 \%$ of the global population, during the 15 year period. An additional $20 \%$ of humanity could access "basic" water services (i.e., water from an improved source within a 30-minute round trip). Thus, we project that basic water access for all may be achieved around 2030. At the recent development rate, however, it may be closer to 2060 before all people have safely managed water on their premises.

While development is advancing rapidly, it is not yet at a pace that will sustain all humankind with clean energy and clean water by 2030 . Accelerating our transition to clean energy and water systems for everyone, everywhere by 2030 cannot wait for the discovery of new technologies. Instead, we need to identify, emulate, and expeditiously scale-up viable solutions to simultaneously pursue both global goals and do so without further compromising our planet's ecological life support systems. The national case studies below show how an integrated approach to the SDGs for water and energy could provide a viable means for doing so.

The present article aims to guide this pursuit by examining the challenges and opportunities at the energy-water nexus of sustainable development. First, we examine historical sustainable development at 
this nexus. We then place this development in the context of integration across the scales of governance, from a local to national to international scale, using SDGs 6 and 7 as our framework. India, Ghana, and Morocco provide poignant case studies. Finally, we derive lessons and recommendations for how nations may utilize SDG targets as a means to unify, and thus hopefully expedite, national initiatives for clean energy and clean water for all.

\section{Sustainable Development at the Energy-Water Nexus}

Realizing SDGs for energy and water access is premised upon harmonizing the energy and water policies on a national scale. In some cases, they are already well-aligned. In other cases, further attention to compatibility and integration is still needed to achieve the potential for success at the water-energy nexus by 2030 .

Integrated policies recognize that energy and water systems are interdependent. For instance, it can be both energy- and water-intensive to manufacture the technologies needed to extract and refine natural resources for clean power and potable water (e.g., photovoltaic (PV) solar panels, pumps and pipes, wind and water turbines, and so on).

The United Nations attributes about $15 \%$ of global water withdrawals to energy production [UNESCO, 2018]. Accessing energy uses water in upstream energy resource collection processes and electricity production (e.g., [IEA, 2013; Mekonnen et al., 2015; Tan, Zhi, 2016]). Interdependencies on the upstream side of energy production focus on the consumption and pollution of water to create fossil fuels, nuclear fuel, and corn-based biofuel. Thus, each of these primary energy sources include substantial quantities of "embodied water."

Water is also vital for large hydroelectric and thermoelectric power generators. Among the most waterintensive electricity generation technologies are concentrated solar power and coal-fired generating facilities with carbon capture and sequestration capabilities [Macknick et al., 2012]. Such power plants consume the most water when using a recirculating cooling system. By contrast, non-thermal renewables, such as wind and hydropower, have the lowest water consumption factors. These renewable technologies have minimal embodied water and thus would be preferable in areas of ongoing water insecurity.

Thus, clean water also includes "embodied energy." Energy-water nexus studies focus on how accessing water uses energy for the diversion of flow upstream, purification and desalination, water temperature control, and wastewater treatment (e.g., [Kahrl, Roland-Holst, 2008; International Energy Agency, 2016; Copeland, Carter, 2017]). Some of these studies also explicitly highlight the relationship between these interdependencies and climate change (e.g., [Rothausen, Conway, 2011; Pittock et al., 2015]), which threatens to disrupt historical water cycle patterns.

The global nature of the energy-water nexus supports the need for the integration of international goals for energy and water. Weitz, et al. assert that formulating integrated water, energy, and food SDGs will make them more cost-effective, while reducing the conflict between them and contributing to sustainable resource use [Weitz et al., 2014]. Yumkella and Yillia posit the need for "a more coordinated approach to sustainable resources management, which in turn requires concerted action in all spheres of influence and at all levels of implementation" [Yumkella, Yillia, 2015, p. 8]. They urge the commitment of resources to implement concrete actions that realize the energy-water nexus approach. Weinthal, when analyzing the Sustainable Development Goals in global environmental politics, asserts that "Whereas the [UN Millennium Development Goals (MDGs) for 2015] were largely silent on such nexus issues, the implementation of the SDGs requires scholars to examine the implementation of the SDG for water in relation to the SDGs for energy" [Weinthal, 2018, p. 43].

Our Table 1 here responds to Weinthal's critique by aligning common national policy goals at the energywater nexus with corresponding SDG targets [UN General Assembly, 2017]. The symmetry we present across energy and water targets provides a clear framework for governments to pursue more integrated policy-making with respect to universal access, natural resource quality, use efficiency, cooperation, and technology transfer. Policy integration at the energy-water nexus is also promoted by other SDG targets (e.g., 6.5, 6.6, 9.4, 12.2, 12.5, 13.2 and 15.9).

National attention to the energy-water nexus echoes this call for integrated policies, but largely without linking these national efforts to global frameworks. Many country case studies suggest the need for better national level coordination across energy and water policies and their implementation. For example, Scott, et al., employ case studies of US regions to examine the institutional and policy issues of the energy-water nexus on local and national scales [Scott et al., 2011]. They highlight the importance of institutions in solving nexus challenges. Fan, et al.'s study of potentially synergistic energy, water, and climate policies in China suggests a similar need for an integrated policy framework [Fan et al., 2018]. Using Israel as a case study, Teschner, et al., posit that integrated transition management of energy and water systems should recognize these systems' interdependencies [Teschner et al., 2012]. Siddiqi and Anadon further propose integrated assessments of energy use in water-intensive industries in the Middle East region [Siddiqi, Anadon, 2011].

Pittock, et al. examine the role of national governance structures in policy and investment decisions to address the energy-water nexus and its relationship to climate, framing such policies and investments as 
Table 1. The UN Sustainable Development Goals for 2030 Provide Nations with Specific Policy Targets at the Energy-Water Nexus

\begin{tabular}{|l|l|l|}
\hline National Policy Goals & \multicolumn{1}{|c|}{ 2030 Energy SDG Targets } & 2030 Water SDG Targets \\
\hline $\begin{array}{l}\text { Universal access to } \\
\text { affordable energy and } \\
\text { water }\end{array}$ & $\begin{array}{l}\text { 7.1 Ensure universal access to affordable, } \\
\text { reliable, and modern energy services }\end{array}$ & $\begin{array}{l}\text { 6.1 Achieve universal and equitable access to safe and } \\
\text { affordable drinking water for all }\end{array}$ \\
\hline $\begin{array}{l}\text { Energy and water } \\
\text { quality }\end{array}$ & $\begin{array}{l}\text { 7.2 Substantially increase the share of } \\
\text { renewable energy in the global energy mix }\end{array}$ & $\begin{array}{l}\text { 6.2 Improve water quality by reducing pollution, eliminating } \\
\text { dumping and minimizing the release of hazardous chemicals } \\
\text { and materials, halving the proportion of untreated wastewater, } \\
\text { and substantially increasing recycling and safe reuse globally }\end{array}$ \\
\hline $\begin{array}{l}\text { Energy and water-use } \\
\text { efficiency }\end{array}$ & $\begin{array}{l}\text { 7.3 Double the global rate of improvement in } \\
\text { energy efficiency }\end{array}$ & $\begin{array}{l}\text { 6.3 Substantially increase water-use efficiency across all sectors } \\
\text { and ensure sustainable withdrawals and supply [...] }\end{array}$ \\
\hline $\begin{array}{l}\text { International } \\
\text { cooperation and } \\
\text { technology transfer }\end{array}$ & $\begin{array}{l}\text { 7.4 Enhance international cooperation to } \\
\text { facilitate access to clean energy research and } \\
\text { technology [...] }\end{array}$ & $\begin{array}{l}\text { 6.4 Expand international cooperation and [...] support to } \\
\text { developing countries in water- and sanitation-related activities } \\
\text { and programs, including [...] technologies }\end{array}$ \\
\hline Source: [UN General Assembly, 2017]. & \\
\hline
\end{tabular}

necessary for sustainable development [Pittock et al., 2015]. Hussey and Pittock assert that national-level policy fragmentation is exacerbating challenges facing energy and water sectors [Hussey, Pittock, 2012]. They cite an Ecology and Society special feature dedicated to case studies that examine energy and water system interdependence, identifying the lack of and need for integrated policies and highlighting barriers to such integration. The authors of the studies in the special feature examine cases of energy-water interdependence challenges in the United States, the Netherlands, Italy, and elsewhere [Stillwell et al., 2011; Bonte et al., 2011]. These challenges parallel those introduced above, including water consumption by thermal power plants, GHG emissions from electricity use in water treatment plants, risks of underground thermal energy storage to groundwater supplies, and energy and water use in biomass production [Bonte et al., 2011; Dalla-Marta et al., 2011]. Based on a comparison of water consumption from energy production for over 150 countries, Spang, et al., also emphasize the need for improved data quality and reporting standards on a global scale [Spang et al., 2014].

A few studies link the need for national and local integration of energy and water policies with nations' abilities to meet international goals (e.g., [Rasul, 2016; Biermann et al., 2017; Rivera et al., 2017]). Rasul asserts that in South Asia, "poor sectoral coordination and institutional fragmentation have triggered an unsustainable use of resources and threaten the long-term sustainability of food, water, and energy security in the region and also posed challenges to achieving the Sustainable Development Goals (SDGs)" [Rasul, 2016, p. 14]. Biermann, et al., assert that the SDGs' success depends upon institutional factors such nations' formalization of commitments, integration of sectoral policies, and "effective translation between global and national aspirations" [Biermann et al., 2017, p. 28]. Rivera et al. examines the potential for the application of global sustainability standards at the city level, using Bogota, Colombia, as a case study. Their findings: global standards and goals can help to legitimize local actors and sustainability programs [Rivera et al., 2017]. These studies highlight the need for an examination of how the energy and water SDGs intersect with national and local-level integration of energy and water policies.

\section{National and Local Focus on Mutually Reinforcing Energy-Water Initiatives}

At the local to regional levels, activities that advance energy access may as a byproduct reduce water access and vice-versa. Mining and refining fossil and nuclear fuels, irrigating biofuel crops, and thermoelectric power generation, as noted above, all consume and/or pollute nearby water. Conversely, energy is expended to desalinate, treat, pressurize, and pump water across human settlements.

Nonetheless, when the SDGs were launched in 2015, access to water and electricity were rising in tandem across the 191 reporting nations. Figure 1 charts this relationship. In nations with minimal access to electricity, only about $40 \%$ of residents had basic water access, Figure 1(a). Meanwhile, Figure 1(b) shows that access to improved water on one's own premises was nearly absent until electricity reached $5 \%$ or more of a nation's population. Thereafter, both basic and on-site water access converged upon 100\% of people in nations with the greatest electricity access. These data support the notion of the advantages offered by conscientious, coordinated policy-making and the implementation across sectors and scales of government influencing the energy-water nexus.

Ways to leverage energy and water system interdependencies tend to focus on either the local, national, or regional level (e.g., [Servert et al., 2016; Sklarew, Sklarew, 2017; Kumar et al., 2018]). Al-Kharaghouli, et al. examine site-specific parameters for desalination powered by wind and solar in the Arab region [Al-Kharaghouli et al., 2009]. Servert, et al. analyze the synergies of solar-powered desalination of seawater for mining operations in Chile, focusing on cost comparisons with desalination using gridsupplied electricity [Servert et al., 2016]. Sklarew and Sklarew note the critical role of local and national institutional support in enabling the deployment of hydropower micro-turbines that can produce electricity from water flowing through drinking water pipes or storm water mitigation systems [Sklarew, 
a) Basic Water Access

$$
\begin{aligned}
& y=0.54 x+43 \\
& \left(r^{2}=0.76 ; p<0.0001\right)
\end{aligned}
$$

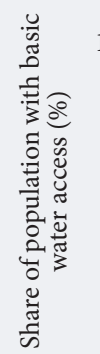

Note: data provided across 191 nations reporting in 2015.

Sources: [UNICEF, 2017; World Bank, 2018b]. б) Access to Improved Water on Premises

$$
\begin{aligned}
& y=0.96 x-5 \\
& \left(r^{2}=0.82 ; p<0.0001\right)
\end{aligned}
$$

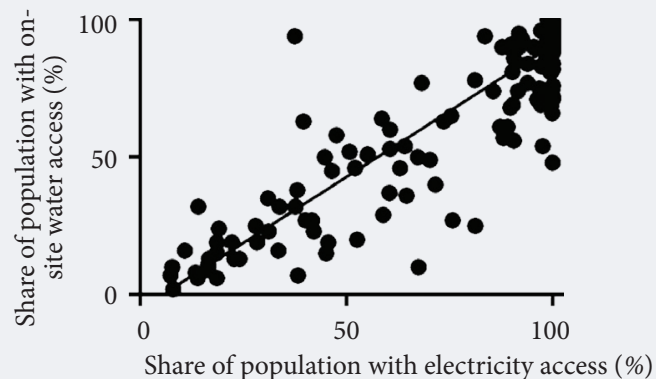

Sklarew, 2017]. Others have reviewed the local nexus benefits of "floatovoltaics," tethered photovoltaic power plants floating atop reservoirs and other surface waters [Kumar et al., 2018; Sengupta, 2017].

None of these studies explain how global frameworks for energy and water systems should combine with local, national, and regional policy frameworks. The existing work does establish a foundation for examining ways in which global goals for energy and water access could influence national governments' abilities to develop synergistic energy and water policies. The current study offers a first analysis of this relationship and the implications for policies that leverage energy-water complementarities and interdependencies to advance universal access to both clean electricity and clean water in the future.

\section{Influence of Sustainable Development upon Governments' Energy and Water Policies}

A quarter century passed between the drafting of the Rio Declaration and the establishment of the United Nations Sustainable Development Goals in 2015. During this period, the portion of humanity with access to electricity rose 17 percentage points, from $71 \%$ to $87 \%$ [World Bank, 2018b]. Meanwhile, access to improved water sources increased by 15 percentage points, from $76 \%$ to $91 \%$.

Many nations that demonstrated greater progress on electricity access and clean water access from 1990 to 2015 accomplished these advances largely through separate initiatives to address energy and water. The top twenty performers included India and Ghana. Both nations are on track to achieve SDGs for energy and water access before 2030. Their governments' programs reveal the global need for linkages between energy and water access policies to more efficiently and effectively improve electricity and clean water access hereafter.

Over 25 years, basic water access expanded from $70 \%$ to $94 \%$ of Indians [Ritchie, Roser, 2018]. The portion with electricity access doubled, from $43 \%$ to $88 \%$ [World Bank, 2018a]. To accomplish these advances, India's government established the Rajiv Gandhi National Drinking Water Mission in 1991, which emphasized community participation in improving clean water access. The Bharat Nirman Program, established in 2005, shifted access from wells and boreholes to pipe systems. Concurrently, to promote increased electricity access, the Indian government implemented programs for grid connections and projects for renewable energy expansion. Connectivity programs have included a 1989 single-point connection program for households below the poverty line, as well as the Electricity Act of 2003, which obliged the government to supply electricity to rural areas through grid extension and distributed generation. Following this mandate, in 2005 the government established the Rajiv Gandhi Grameen Vidyutikaran Yojana (RGGVY) rural electrification program [Nath, 2011].

Ghana provided water access to one third more of its people in 2015 (89\%) than in 1990 (56\%). At the same time electricity access climbed remarkably from $24 \%$ to $76 \%$. To achieve this progress, the Ghanaian government based its water policies on the year 2000's successful MDG target to halve the proportion of people without access to safe drinking water by 2015 [United Nations, 2015]. Ghana's improvements to water access have relied upon groundwater technologies such as boreholes, handdug wells, and community pipe systems. Meanwhile, electricity access improvements have emerged from large-scale and small-scale grid connections, as well as off-grid solar installations. In 1988, the government collaborated with the utilities agencies to connect all of the regions and districts in the 
country through the National Electrification Programme. In 1989, the government established the National Electrification Fund and the Self-Help Electrification Programme (SHEP), which offered to connect communities within 20 kilometers of the existing grid. Communities provided the low voltage wooden distribution poles [Clark et al., 2005].

Aligned with SDG targets in Table 1, both the Indian and Ghanaian governments have implemented some integrated policies and initiatives that jointly promote water conservation and electricity access. These policies have also advanced energy-related greenhouse gas emissions reduction goals.

For example, the Indian government initiated national-level renewables projects that do not consume large quantities of water. Investments include large-scale wind power, family biogas plants, and solar streetlights, lanterns, and PV systems. Some of the government's sponsored projects - micro-hydropower plants - leverage existing waterways without contributing to water pollution or consumption [Arora et al., 2010]. After the introduction of the SDGs, Prime Minister Modi announced the Saubhagya Scheme in 2017, with the goal of electrifying all households in India by December 2018 and a budget of $\$ 2.5$ billion to achieve it [Government of India, 2017]. A slew of related policies also emerged, including several introduced in 2017 to advance the development of mini-grids based on renewable energy. In conjunction with private sector firms, local governments are implementing renewables-based mini-grids, reverse osmosis water purification projects and the floatovoltaics prototype noted above. Several government programs introduced in 2018 promote biomass, wind, and solar power generation as well.

Ghana continues to grapple with electricity access and water security challenges. The Ghanaian government's policies have included a Sustainable Energy for All Action Plan launched in 2012. The plan includes the 2010 goal of 100 percent access by 2020 [Energy Commission of Ghana, 2012]. In 2011, the government passed the Renewable Energy Act to shift electricity generation away from large hydropower production by 2020. The Act established the legal framework for the creation of policy tools such as feed-in tariffs and net metering [IEA, 2014]. In 2013 and 2016, the government implemented, then updated, feed-in tariffs for wind, solar photovoltaics, small hydropower, biomass, biogas, and geothermal power. Following the introduction of the SDGs, Ghana's government implemented a 2018 rollout of a national rooftop solar program aiming to install $200 \mathrm{MW}$ of rooftop solar across the country. Some local Ghanaian projects that leverage energy-water complementarities include solar-powered water pumps as an alternative to piped water.

Having achieved universal access to electricity in 2015, Morocco demonstrates how such an accomplishment can help to support water access as well. Moroccans pushed through government policies that began to jointly address clean water and electricity access even before the introduction of the SDGs. Although energy and water policies are handled by separate government offices, some of their policies reflect efforts to coordinate across the single ministry that houses them. Following the launch of the Global Rural Electrification Plan in 1995, the National Office of Electricity aimed to connect most villages to the national grid, while using off-grid renewable energy systems to provide electricity for remote communities. These systems are powered by wind, hydropower, or PV. In 2004, a public-private partnership emerged to develop and manage 15 photovoltaic drinking water pumping systems to serve isolated communities. The government's 2009 Renewable Energy Law provides policy support and a regulatory framework for solar PV, solar thermal, and wind power production and commercialization. In 2015, the government adopted Law 58-15, which introduced net metering for solar PV and onshore wind plants connected to the centralized grid.

To promote clean energy use in irrigation systems, in 2013, Morocco's Ministry of Energy, Mining, Water, and Environment initiated the National Program for Solar Pumping in Irrigation Water Saving Projects. The project aims to reduce butane use by offering grants to small and mid-sized farms to purchase solar pumps for small-scale irrigation [Government of Morocco, 2016]. Following the introduction of the SDG, and Morocco's hosting of the Climate Change Conference of the Parties (COP 22) in 2016, the Moroccan government has focused on advancing the use of solar energy. Morocco's Renewable Energy and Energy Efficiency National Development Agency is working in partnership with the United Nations Development Programme. UNDP has committed "to establish quality standards for solar pumping, advocate for the adoption of photovoltaic pump systems for irrigation and promote investment in renewable energy technologies" [UNDP, 2017a].

\section{Preparing More Integrated Solutions for Future Energy-Water Development}

India, Ghana, and Morocco all have actively and seriously invested in meeting the clean water and electricity needs of their people over the past generation. To varying extents, they are reducing the water embodied in their power production and the energy embodied in their drinking water in order to achieve one (Morocco) or both SDG targets 6.1 and 7.1 for universal access. Still, these nations' leaders and their counterparts elsewhere are not advancing infrastructure at a sufficient pace to ensure all citizens receive "safely managed" water in their own homes by 2030 . Furthermore, despite technological advances and price drops, each has substantially decreased the share of renewable energy in their energy mix from 1990 to 2015. Figure 2 illustrates that we are still losing ground with respect to sustaining people with clean energy. This has disastrous implications for future climate mitigation (SDG 13), sustainable infrastructure 


\section{Figure 2. 1990-2015 Worldwide Trends and Those for Three Case Studies: Ghana, India and Morocco}

a) Populations' Electricity Access (SDG 7.1)

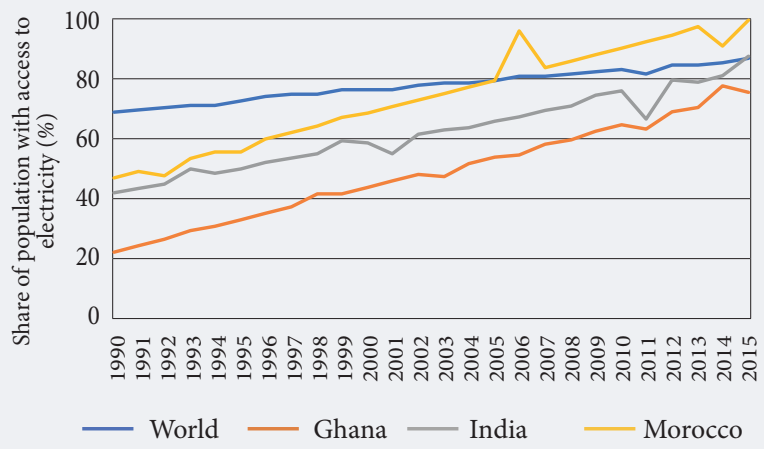

b) Renewable Energy Share of Energy Consumption (SDG 7.2)

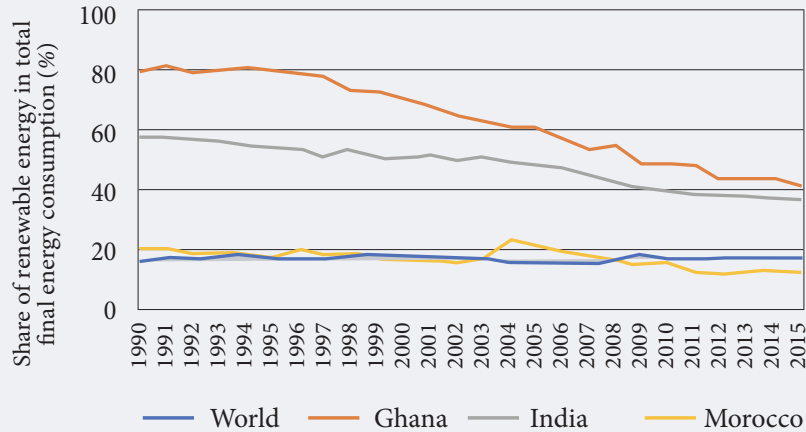

Source: [World Bank, 2018a].

(SDG 9), and responsible consumption and production (SDG 12) as well. What can be done to turn this trend around?

Nations that continue to struggle to achieve electricity and clean water access can derive lessons from these countries' experiences. India, Ghana, and Morocco demonstrate that the integration of clean energy access and water security policies at the national level can encourage local projects that address local communities' unique electricity and water needs. However, just as these local initiatives require national frameworks to support them, national policies can benefit from supportive global goals such as the SDGs if they are designed to highlight complementarities and minimize conflicts for nations striving to achieve them.

In assessing national-level progress on SDG 7, affordable, reliable, and modern energy for all, the United Nations recognizes that "national priorities and policy ambitions still need to be strengthened to put the world on track to meet the energy targets for 2030" [UN, 2018]. The United Nations Development Programme (UNDP) has committed itself to supporting nations' progress on meeting the SDG goals. The UNDP's 2018-21 Strategic Plan outlines two support platforms through which UNDP will provide such support for the national achievement of integrated policies to meet SDG targets [UNDP, 2017a]. These platforms bridge global and national goals. The country-support platform will "help countries design and carry out integrated solutions, where problems require action across economic, social, and environmental issues" [UNDP, 2017b]. The global development advisory and implementation services platform aims to "provide technical and policy advisory support to country platforms and UNDP country programmes; and support UNDP global knowledge, innovation and partnership-building efforts within the UN development system (UNDS), as well as with international financial institutions (IFIs) and other partners" [UNDP, 2017b].

\section{Conclusion}

If the trends of the past quarter century are a reliable predictor, we find that virtually all of humanity should have access to clean water within a thirty-minute trip from home and back by 2030 . Electricity should be essentially universal within a decade after that. Getting both into every home, however, may be yet another generation away.

Doing so will be critical to realizing the promise of sustainable development, i.e., to meet human needs in perpetuity. For instance, Costa et al. [Costa et al., 2009] found that providing rural Ghanaian women such access decreases their "time poverty," providing them more time to pursue paid work. Thus, integrated access to clean water (SDG 6) and clean energy (SDG 7) in homes may ultimately help alleviate poverty (SDG 1). Poverty alleviation is also a primary goal for international agencies like UNDP and the World Bank. Thus, they have a strong interest in expediting the full achievement of SDG 6 and 7 targets by 2030 (if not sooner).

We assert that the integrative energy-water nexus approach should play a central role in accelerating clean energy and clean water access globally. In the most basic sense, this approach entails managing the amount of embodied energy used to develop and deliver clean water and, reciprocally, the quantity of clean water consumed or fouled in order to develop and deliver our energy to us. The energy-water nexus also challenges us to think beyond tradeoffs between energy access and water access. Instead, we seek for both axes of access to continue rising together in "win-win" scenarios (Figure 1). To do so, 
these interrelated systems must be transformed by government policies that catalyze joint energy-water infrastructure, for example, floatovoltaics on reservoirs, hydropower micro-turbines in water pipes, desalination plants fueled by sewage treatment plant methane, and hydrogen fuel cell batteries that reconstitute clean water from fresh air.

To raise the persistently low portion of renewable energy in our growing energy use (Figure 2), nations need to think intelligently about development along the energy-water nexus. It would not suffice for India to double its 2016 renewable energy supply in two to three years or for Morocco to increase its own from 13\% of installed power in 2015 to $42 \%$ in 2020 [World Energy Council, 2018]. Their policy and technology choices additionally need to incorporate impacts and opportunities associated with water security and other ecosystem services (e.g., SDGs 13-15).

The framework of the policy goals and SDG targets presented in Table 1 above provides a model for nations to operationalize SDG priorities in national policymaking. SDG targets serve as criteria to evaluate national policies in a more integrated multi-sectoral manner. Still, this set of criteria - affordable access, quality, efficiency and technical cooperation - is illustrative, not normative. Natural resource development agencies are encouraged to adapt or build upon this set in order to create their own framework to facilitate policy integration at the energy-water nexus.

The energy-water nexus scholarship to date has identified the interdependencies on global and national scales, the challenges arising from them, and the need for effective, unified national policies to address these challenges. This study recommends the development of such integrated national policies in the context of existing global frameworks such as the SDGs. Such framing will align national energy and water policies under broader goals, enabling policymakers to recognize conflicts and leverage complementarities. This global framing for national efforts requires coordination between national governments and international agencies such as the UNDP and the World Bank. UNDP has pledged support for national goals. This needs to include education, capacity-building, and tools that can enable national governments to effectively integrate their clean energy and water access policies. UN support for the methodological integration of sustainable development across SDGs targets, as illustrated above for the energy-water nexus, will be critical to nations' success in achieving SDGs targets for 2030 and ultimately realizing sustainable development globally in perpetuity.

\section{References}

Al-Karaghouli A., Renne D., Kazmerski L.L. (2009) Solar and wind opportunities for water desalination in the Arab regions // Renewable and Sustainable Energy Reviews, vol. 13, no 9, pp. 2397-2407.

Arora D.S., Busche S., Cowlin S., Engelmeier T., Jaritz J., Milbrandt A., Wang S. (2010) Indian Renewable Energy Status Report: Background Report for DIREC 2010 (NREL/TP-6A20-48948, 991558), Golden, CO: National Renewable Energy Laboratory. Available at: http://www.ren21.net/Portals/0/documents/Resources/Indian_RE_ Status_Report.pdf, accessed 12.08.2018.

Bieber N., Ker J.H., Wang X., Triantafyllidis C., van Dam K.H., Koppelaar R.H.E.M., Shah N. (2018) Sustainable planning of the energy-water-food nexus using decision making tools. Energy Policy, vol. 113, pp. 584-607. Available at: https://doi.org/10.1016/j.enpol.2017.11.037, accessed 25.09.2018.

Biermann F., Kanie N., Kim R. (2017) Global governance by goal-setting: The novel approach of the UN Sustainable Development Goals. Current Opinion in Environmental Sustainability, vol. 26-27, pp. 26-31. DOI: 10.1016/j. cosust.2017.01.010.

Bonte M., Stuyfzand P.J., Hulsmann A., Van Beelen P. (2011) Underground Thermal Energy Storage: Environmental Risks and Policy Developments in the Netherlands and European Union. Ecology and Society, vol. 16, no 1, article 22 [online]. Available at: http://www.ecologyandsociety.org/vol16/iss1/art22/, accessed 18.12.2017.

Clark A., Davis M., Eberhard A., Gratwick K., Wamukonya N. (2005) Power Sector Reform in Africa: Assessing the Impact on Poor People (Report Prepared by the Graduate School of Business, University of Cape Town), Washington, D.C.: World Bank.

Copeland C., Carter N.T. (2017) Energy-Water Nexus: The Water Sector's Energy Use, Washington, D.C.: Congressional Research Service.

Cosgrove W.J., Rijsberman F.R. (2000) World Water Vision: Making Water Everybody's Business, London: Earthscan Publications.

Costa J., Hailu D., Silva E., Tsukada R. (2009) The Implications of Water and Electric Supply for the Time Allocation of Women in Rural Ghana (Working Paper no 59), Brasilia: International Policy Centre for Inclusive Growth, United Nations Development Programme.

Dalla-Marta A., Natali F., Mancini M., Ferrise R., Bindi M., Orlandini S. (2011) Energy and Water Use Related to the Cultivation of Energy Crops: A Case Study in the Tuscany Region. Ecology and Society, vol. 16, no 2, article 2 [online]. Available at: http://www.ecologyandsociety.org/vol16/iss2/art2/, accessed 17.10.2018.

Energy Commission of Ghana (2012) Sustainable Energy for All Action Plan, Accra: Energy Commission of Ghana.

Fan J.-L., Kong L.-S., Zhang X. (2018) Synergetic effects of water and climate policy on energy-water nexus in China: A computable general equilibrium analysis. Energy Policy, vol. 123, pp. 308-317. Available at: https://doi. org/10.1016/j.enpol.2018.09.002, accessed 18.12.2017. 
Government of India (2017) Guidelines for Pradhan Mantri Sahaj Bijli Har Ghar Yojana (Saubhagya), Delhi: Ministry of Power, Government of India.

Government of Morocco (2016) Programme for Large-scale Deployment of Solar Pumping in Irrigation Water Saving Projects, Rabat: Ministry of Energy, Mining, Water and Environment, Government of the Kingdom of Morocco.

Hussey K., Pittock J. (2012) The Energy-Water Nexus: Managing the Links between Energy and Water for a Sustainable Future. Ecology and Society, vol. 17, no 1, article 31 [online]. Available at: http://dx.doi.org/10.5751/ES-04641-170131, accessed 18.12.2017.

IEA (2013) Renewable Energy Act. Law 13-09, Paris: International Energy Agency. Available at: https://www.iea.org/ policiesandmeasures/renewableenergy/?country=Morocco, accessed 18.12.2017.

IEA (2014) Renewable Energy Act 2011, Paris: International Energy Agency. Available at: https://www.iea.org/ policiesandmeasures/pams/ghana/name-130043-en.php, accessed 18.12.2017.

IEA (2016) World Energy Outlook 2016: Water-Energy Nexus, Paris: International Energy Agency.

IEA (2018) Global Energy and CO2 Status Report 2017, Paris: International Energy Agency. Available at: https://www. iea.org/publications/freepublications/publication/GECO2017.pdf, accessed 10.05.2018.

ILEC, UNEP (1993) Data Book of Lake Environments: A Survey of the State of World Lakes, Otsu, Japan: International Lake Environment Committee, United Nations Environmental Programme.

Kahrl F., Roland-Holst D. (2008) China’s water-energy nexus. Water Policy, vol. 10, pp. 51-65. Available at: https:// doi.org/10.2166/wp.2008.052, accessed 10.05.2018.

Kumar N.M., Kanchikere J., Mallikarjun P. (2018) Floatovoltaics: Towards improved energy efficiency, land and water management. International Journal of Civil Engineering and Technology, vol. 9, pp. 1089-1096.

Macknick J., Newmark R., Heath G., Hallett K.C. (2012) Operational water consumption and withdrawal factors for electricity generating technologies: A review of existing literature. Environmental Research Letters, vol. 7, article 045802 [online]. Available at: https://doi.org/10.1088/1748-9326/7/4/045802, accessed 17.10.2018.

Mekonnen M., Gerbens-Leenes, P.W., Y. Hoekstra, A. (2015) The consumptive water footprint of electricity and heat: a global assessment. Environmental Science: Water Research \& Technology, vol. 1, pp. 285-297. Available at: https:// doi.org/10.1039/C5EW00026B, accessed 17.10.2018.

Nath A. (2011) India’s Progress Toward Achieving the Millennium Development Goals. Indian Journal of Community Medicine, vol. 36, no 2, pp. 85-92.

Pittock J., Hussey K., Dovers S. (2015) Climate, Energy and Water, New-York: Cambridge University Press.

Rasul G. (2016) Managing the food, water, and energy nexus for achieving the Sustainable Development Goals in South Asia. Environmental Development, vol. 18 (April), pp. 14-25.

Ritchie H., Roser M. (2018) Water Access, Resources \& Sanitation [online]. Available at: https://ourworldindata.org/ water-access-resources-sanitation, accessed 10.06.2018.

Rivera J.M., Munoz M.J., Moneva J.M. (2017) Revisiting the Relationship Between Corporate Stakeholder Commitment and Social and Financial Performance. Sustainable Development, vol. 25, no 6, pp. 482-494.

Rothausen S.G.S.A., Conway D. (2011) Greenhouse-gas emissions from energy use in the water sector. Nature Climate Change, vol. 1, pp. 210-219. Available at: https://doi.org/10.1038/nclimate1147, accessed 10.06.2018.

Sachs J., Schmidt-Traub G., Kroll C., Lafortune G., Fuller G. (2018) SDG Index and Dashboards Report 2018, New York: Bertelsmann Stiftung and Sustainable Development Solutions Network (SDSN).

Scott C.A., Pierce S.A., Pasqualetti M.J., Jones A.L., Montz B.E., Hoover J.H. (2011) Policy and institutional dimensions of the water-energy nexus. Energy Policy, vol. 39, pp. 6622-6630. Available at: https://doi.org/10.1016/j. enpol.2011.08.013, accessed 15.09.2018.

Sengupta D. (2017) NTPC installs India's largest floating solar PV plant in Kerala. The Economic Times, 10.03.2017. Available at: https://economictimes.indiatimes.com/industry/energy/power/ntpc-installs-indias-largest-floatingsolar-pv-plant-in-kerala/articleshow/57577004.cms, accessed 28.06.2018.

Servert J., Cerrajero E., Fuentealba E. (2016) Synergies of solar energy use in the desalination of seawater: A case study in northern Chile. Paper presented at the SOLARPACES 2015: AIP International Conference on Concentrating Solar Power and Chemical Energy Systems. Available at: https://aip.scitation.org/doi/10.1063/1.4949232, accessed 28.06.2018.

Siddiqi A., Anadon L.D. (2011) The water-energy nexus in Middle East and North Africa. Energy Policy, vol. 39, pp. 4529-4540. Available at: https://doi.org/10.1016/j.enpol.2011.04.023, accessed 10.06.2018.

Sklarew J.F., Sklarew D.M. (2017) Empowering Resilience in Energy and Water Systems: Addressing Barriers to Implementation of Urban Hydroelectric Micro-turbines (The CIP Report), Fairfax, VA: George Mason University.

Spang E.S., Moomaw W.R., Gallagher K.S., Kirshen P.H., Marks D.H. (2014) The water consumption of energy production: An international comparison. Environmental Research Letters, vol. 9, no 10, article 105002. Available at: http://iopscience.iop.org/article/10.1088/1748-9326/9/10/105002/pdf, accessed 15.06.2018.

Stillwell A.S., King C.W., Webber M.E., Duncan I.J., Hardberger A. (2011) The Energy-Water Nexus in Texas. Ecology and Society, vol. 16, no 1, article 2 [online]. Available at: http://www.ecologyandsociety.org/vol16/iss1/art2/, accessed 19.07.2018.

Tan C., Zhi Q. (2016) The Energy-water Nexus: A literature Review of the Dependence of Energy on Water. Energy Procedia, vol. 88, pp. 277-284. Available at: https://doi.org/10.1016/j.egypro.2016.06.154, accessed 24.08.2018.

Teschner N., McDonald A., Foxon T.J., Paavola J. (2012) Integrated transitions toward sustainability: The case of water and energy policies in Israel. Technological Forecasting and Social Change, vol. 79, no 3, pp. 457-468. 
UN (2015) Millennium Development Goals Report 2015, New York: United Nations Publications.

UN (2018) The Sustainable Development Goals Report 2018, New York: United Nations Publications.

UN DESA (2017) World Population Prospects: The 2017 Revision [online]. Available at: http://www.un.org/en/ development/desa/population/publications/database/index.shtml, accessed 10.05.2018.

UN General Assembly (2017) Work of the Statistical Commission pertaining to the 2030 Agenda for Sustainable Development (A/RES/71/313). Available at: http://ggim.un.org/documents/A_RES_71_313.pdf, accessed 24.08.2018

UNDP (2017a) Country programme document for the Kingdom of Morocco, Geneva: United Nations.

UNDP (2017b) United Nations Development Programme Strategic Plan 2018-21, Geneva: United Nations.

UNESCO (1992) The Rio Declaration on Environment and Development, Paris: United Nations Educational, Scientific and Cultural Organization.

UNESCO (2018) The United Nations World Water Development Report 2018: Nature-Based Solutions for Water, Paris: United Nations Educational, Scientific and Cultural Organization.

UNICEF (2017) Drinking Water [online database]. Available at: https://data.unicef.org/topic/water-and-sanitation/ drinking-water/, accessed 10.05.2018.

UNSD (2018) SDG Indicators [online database]. Available at: https://unstats.un.org/sdgs/indicators/database, accessed 10.05.2018.

Weinthal E. (2018) The Sustainable Development Goals in Global Environmental Politics. A Research Agenda for Global Environmental Politics (eds. P. Dauvergne, J. Alger), Cheltenham: Edward Elgar Publishing, pp. 39-49.

Weitz N., Nilsson M., Davis M. (2014) A Nexus Approach to the Post-2015 Agenda: Formulating Integrated Water, Energy, and Food SDGs. SAIS Review of International Affairs, vol. 34, pp. 37-50. Available at: https://doi. org/10.1353/sais.2014.0022, accessed 17.09.2018.

WHO, UNICEF (2017) Joint Monitoring Programme for Water Supply, Sanitation and Hygiene. Program Data [online database]. Available at: https://washdata.org/data accessed 10.06.2018.

World Bank (2018a) Tracking SDG7: The Energy Progress Report 2018, Washington, D.C.: World Bank. Available at: https://trackingsdg7.esmap.org/, accessed 22.10.2018.

World Bank (2018b) World Bank Development Data Group Open Data [online database]. Available at: https://data. worldbank.org/, accessed 10.06.2018.

World Energy Council (2013) World Energy Resources 2013 Survey, London: World Energy Council.

World Energy Council (2018) World Energy Trilemma Report 2018, London: World Energy Council.

Yumkella K.K., Yillia P.T. (2015) Framing the Water-Energy Nexus for the Post-2015 Development Agenda. Aquatic Procedia, vol. 5, pp. 8-12. Available at: https://doi.org/10.1016/j.aqpro.2015.10.003, accessed 17.09.2018. 